Atmos. Chem. Phys., 10, 11359-11371, 2010

www.atmos-chem-phys.net/10/11359/2010/

doi:10.5194/acp-10-11359-2010

(c) Author(s) 2010. CC Attribution 3.0 License.

\title{
Ship-based detection of glyoxal over the remote tropical Pacific Ocean
}

\author{
R. Sinreich ${ }^{1}$, S. Coburn ${ }^{1}$, B. Dix ${ }^{1}$, and R. Volkamer ${ }^{1,2}$ \\ ${ }^{1}$ Department of Chemistry and Biochemistry, University of Colorado at Boulder, Colorado, USA \\ ${ }^{2}$ Cooperative Institute for Research in the Environmental Studies, Boulder, Colorado, USA
}

Received: 1 May 2010 - Published in Atmos. Chem. Phys. Discuss.: 21 June 2010

Revised: 8 November 2010 - Accepted: 21 November 2010 - Published: 1 December 2010

\begin{abstract}
We present the first detection of glyoxal (CHO$\mathrm{CHO}$ ) over the remote tropical Pacific Ocean in the Marine Boundary Layer (MBL). The measurements were conducted by means of the University of Colorado Ship Multi-Axis Differential Optical Absorption Spectroscopy (CU SMAX-DOAS) instrument aboard the research vessel Ronald $\mathrm{H}$. Brown. The research vessel was on a cruise in the framework of the VAMOS Ocean-Cloud-Atmosphere-Land Study - Regional Experiment (VOCALS-REx) and the Tropical Atmosphere Ocean (TAO) projects lasting from October 2008 through January 2009 (74 days at sea). The CU SMAXDOAS instrument features a motion compensation system to characterize the pitch and roll of the ship and to compensate for ship movements in real time. We found elevated mixing ratios of up to $140 \mathrm{ppt} \mathrm{CHOCHO}$ located inside the MBL up to $3000 \mathrm{~km}$ from the continental coast over biologically active upwelling regions of the tropical Eastern Pacific Ocean. This is surprising since CHOCHO is very short lived (atmospheric life time $\sim 2 \mathrm{~h}$ ) and highly water soluble (Henry's Law constant $\left.H=4.2 \times 10^{5} \mathrm{M} / \mathrm{atm}\right)$. This $\mathrm{CHOCHO}$ cannot be explained by transport of it or its precursors from continental sources. Rather, the open ocean must be a source for $\mathrm{CHOCHO}$ to the atmosphere. Dissolved Organic Matter (DOM) photochemistry in surface waters is a source for Volatile Organic Compounds (VOCs) to the atmosphere, e.g. acetaldehyde. The extension of this mechanism to very soluble gases, like $\mathrm{CHOCHO}$, is not straightforward since the air-sea flux is directed from the atmosphere into the ocean. For $\mathrm{CHOCHO}$, the dissolved concentrations would need to be extremely high in order to explain our gas-phase observations by this mechanism $(40-70 \mu \mathrm{M} \mathrm{CHOCHO}$, compared
\end{abstract}

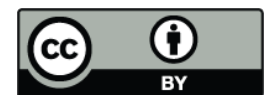

Correspondence to: R. Volkamer (rainer.volkamer@colorado.edu) to $\sim 0.01 \mu \mathrm{M}$ acetaldehyde and $60-70 \mu \mathrm{M}$ DOM). Further, while there is as yet no direct measurement of VOCs in our study area, measurements of the $\mathrm{CHOCHO}$ precursors isoprene, and/or acetylene over phytoplankton bloom areas in other parts of the oceans are too low (by a factor of 10-100) to explain the observed $\mathrm{CHOCHO}$ amounts. We conclude that our $\mathrm{CHOCHO}$ data cannot be explained by currently understood processes. Yet, it supports first global source estimates of $20 \mathrm{Tg} /$ year $\mathrm{CHOCHO}$ from the oceans, which likely is a significant source of secondary organic aerosol (SOA). This chemistry is currently not considered by atmospheric models.

\section{Introduction}

Glyoxal (CHOCHO) is the smallest $\alpha$-dicarbonyl compound. It is primarily formed by oxidation of numerous Volatile $\mathrm{Or}$ ganic Compounds (VOCs) such as aromatics and alkenes, but is also emitted directly into the atmosphere (Calvert et al., 2000; Volkamer et al., 2001; Calvert et al., 2002). VOC oxidation, and thus the $\mathrm{CHOCHO}$ production, is driven by photochemical activity in the atmosphere. Although high peak concentrations could be observed in urban areas mainly due to anthropogenic activity (Volkamer et al., 2005a; Sinreich et al., 2007), the largest global source of CHOCHO is from the oxidation of biogenic VOC emissions, primarily isoprene (Fu et al., 2008; Stavrakou et al., 2009). Major sources also are biomass burning and biofuel usage (Fu et al., 2008). The total continental source of CHOCHO to the atmosphere is constrained by satellite measurements and ranges between 94 and $108 \mathrm{Tg} /$ year (Stravrakou et al., 2009), of which about $50 \%$ are currently explained in terms of known sources (Myriokefalitakis et al., 2008; Fu et al., 2008); the

Published by Copernicus Publications on behalf of the European Geosciences Union. 
remaining $50 \%$ of the $\mathrm{CHOCHO}$ source is currently unaccounted for. Satellite data (Witttrock et al., 2006) in combination with model assumptions regarding the sinks of CHOCHO (TM4) made a first quantification of this source, and indicate that tropical oceans could add an additional $20 \mathrm{Tg} /$ year to the global CHOCHO source (Myriokefalitakis et al., 2008). CHOCHO is rapidly lost by photolysis and reactions with $\mathrm{OH}$ radicals. It can also be taken up in cloud droplets (Ervens et al., 2004), and/or aqueous particles (Liggio et al., 2005; Volkamer et al., 2009a) and form secondary organic aerosols (SOA). The global SOA source from CHO$\mathrm{CHO}$ over land is currently estimated to range from 6.4 to $21 \mathrm{Tg} / \mathrm{yr}$ (Fu et al., 2008; Stavrakou et al., 2009). The atmospheric life time of $\mathrm{CHOCHO}$ is about $1.3 \mathrm{~h}$ for overhead sun conditions (Volkamer et al., 2005a), and the global mean life time is between 2.5 and $3 \mathrm{~h}$ (Myriokefalitakis et al., 2008; Fu et al., 2008; Stavrakou et al., 2009).

Although $\mathrm{CHOCHO}$ has been measured for over two decades (Kieber et al., 1990), CHOCHO measurements continue to be scarce. Also, almost all observations were performed over land and in the Northern Hemisphere (Volkamer et al., 2010). Information over the remote ocean is only available from several satellite instruments. Wittrock et al. (2006) and Vrekoussis et al. (2009) published global maps of CHOCHO using the SCanning Imaging Absorption SpectroMeter for Atmospheric CartograpHY (SCIAMACHY). Worldwide $\mathrm{CHOCHO}$ distribution maps also were derived from the Ozone Monitoring Instrument (OMI, available at http://www.cfa.harvard.edu/ tkurosu/SatelliteInstruments/ OMI/SampleImages/CHOCHO/index.html; Kurosu et al., 2005) and from the Global Ozone Monitoring Experiment 2 (GOME-2; Lerot et al., 2010; Vrekoussis et al., 2010). However, they are not consistent in the amount of CHOCHO, which reflects the fact that measurements from space are inherently difficult to conduct due to low albedo over oceans and cloud coverage (specifically over the tropics).

Attempts to calculate the global $\mathrm{CHOCHO}$ distribution have been made using atmospheric models, including TM4 (Myriokefalitakis et al., 2008), GEOS-Chem (Fu et al., 2008) and IMAGES (Stavrakou et al., 2009). However, a comparison with satellite measurements shows a large mismatch in remote tropical ocean regions: while satellites observe $\mathrm{CHOCHO}$ over the remote tropical ocean the models do not predict any $\mathrm{CHOCHO}$ there. This triggered the question, whether chemical models are missing sources, or whether the satellite retrievals have been affected by a retrieval artifact. Since satellites point to the Earth's surface the latter could be due to absorption interference with chlorophyll in the ocean which is found in parts of the ocean where $\mathrm{CHOCHO}$ was retrieved from satellite (see http://earthobservatory.nasa.gov/ GlobalMaps/view.php?d1=MY1DMM_CHLORA).

In order to investigate this mismatch we have developed the CU SMAX-DOAS device, which is optimized for the deployment on ships (see Sect. 2.2 and Volkamer et al., 2009b), and performed MAX-DOAS measurements of CHOCHO on the research vessel Ronald $\mathrm{H}$. Brown during its cruise through the tropical Pacific Ocean between October 2008 and January 2009.

\section{Measurement}

\subsection{Measurement technique}

For the measurement of CHOCHO the well established Differential Optical Absorption Spectroscopy (DOAS) technique was applied (Platt, 1994). DOAS uses the position and optical density of narrow band absorption features $(<5 \mathrm{~nm}$ width) to selectively detect and quantify trace gases by applying the Lambert-Beer law. It is a remote sensing technique which is intrinsically calibrated and which identifies the trace gases of interest by their characteristic narrow band absorption structures (Platt, 1999). In particular, the MultiAxis (MAX-)DOAS technique employed here uses scattered sunlight observed from multiple viewing directions. This increases the sensitivity to trace gases close to the surface due to differences in the respective light path distributions, i.e. a lower "elevation angle" leads to longer light paths through a trace gas layer near the instrument altitude and thus to a stronger absorption signal (elevation angle is defined as the angle between the horizontal and the pointing direction of the telescope) (e.g. Hönninger and Platt, 2002; van Roozendael et al., 2003; Hönninger et al., 2004; Wagner et al., 2004). Additionally, measurements at different elevation angles provide information about the vertical profile of a trace gas. When assuming a well mixed trace gas layer (e.g. within the atmospheric boundary layer), its vertical extent and concentration can be determined with good accuracy (e.g. Wittrock et al., 2004; Sinreich et al., 2005; Heckel et al., 2005; Frieß et al., 2006). To determine this, typically the trace gas $\mathrm{O}_{4}$ is used. $\mathrm{O}_{4}$ is the oxygen dimer molecule whose concentration is proportional to the concentration of $\mathrm{O}_{2}$ squared. Thus, the concentration profile shape is well known and is quantitatively dependent only on the air pressure. For this reason $\mathrm{O}_{4}$ can be used as a valid tracer of the light path distribution in the atmosphere (e.g. Wagner et al., 2004; Sinreich et al., 2005; Frieß et al., 2006).

MAX-DOAS measurements from ships are rare so far and go along with the challenge of the stabilization of the viewing angle (Kreher et al., 1995; Leser et al., 2003; Wagner et al., 2007; Martin et al., 2009). For this cruise, we actively accounted for the pitch and roll of the ship, as described in Sect. 2.2.

\subsection{Instrumentation}

The University of Colorado Ship MAX-DOAS (CU SMAX-DOAS) instrument consists of a telescope, spectrograph/detector units, and a laptop PC. The telescope collects scattered sunlight, and was mounted on "deck 03 forward" close to the bow of the ship. The telescope is comprised of 
a quartz prism and a quartz lens (cone angle of $0.3^{\circ}$ ) which focuses incoming light on a quartz fiber fixed in the focal plane. The prism is mounted to rotate vertically by a stepper motor $\left(0.09^{\circ}\right.$ motor precision) allowing a rotation of $360^{\circ}$. In zero position (view to horizon), the telescope pointed to $256^{\circ}$ (clockwise) relative to the bow tip of the ship. Spectra of scattered sunlight were acquired sequentially from the following elevation angles: $90^{\circ}, 0.25^{\circ}, 0.6^{\circ}, 1.5^{\circ}, 3.8^{\circ}, 10^{\circ}$, $25^{\circ}, 90^{\circ}, 179.75^{\circ}, 179.4^{\circ}, 178.5^{\circ}, 176.2^{\circ}, 170^{\circ}, 155^{\circ}, 205^{\circ}$, and $-45^{\circ}$. An internal motor encoder reads the position of the motor axis (encoder accuracy $0.18^{\circ}$ ), and software assures that the motor positions are reached. Two inclinometers arranged perpendicularly to each other measured roll and pitch of the ship during measurement with a precision of $0.1^{\circ}$ each. The information from these sensors is processed by software into the coordinate system along the line of sight of the telescope, and is used to drive the stepper motor in such way that it compensates for the ship's movement and keeps the elevation angle on a software determined target level. A third inclinometer was periodically mounted on top of the prism housing to assure the accuracy of our angle stabilization: at a swell of up to $6^{\circ}$ roll (peak to peak) and up to $1.3^{\circ}$ pitch (peak to peak) the deviations were $\pm 0.56^{\circ}$ standard deviation for a $2 \mathrm{~min}$ time period. The integration time of each spectrum was set to $30 \mathrm{~s}$; one sequence of elevation angles was completed after about $8 \mathrm{~min}$. The light is focused by the telescope on a single fiber which is coupled to 3 spectrograph/detector units "QE65000" of Ocean Optics Inc. equipped with two-dimensional CCD-detectors with 1044 wavelength channels (model Hamamatsu S7031-1006). The spectrograph/detector unit used for the $\mathrm{CHOCHO}$ measurements projected a wavelength range from about 415 to $524 \mathrm{~nm}$. The optical spectrometer bench was heated to a temperature of $30^{\circ} \mathrm{C}$ to minimize changes in optical projecting properties while the detector itself was cooled to $0^{\circ} \mathrm{C}$ to reduce dark current. In leg 1 , the spectrometer temperature was stable to $\pm 0.1^{\circ} \mathrm{C}$ except from 21 to 23 October when problems with the heating foil of the spectrometer limited the stability to $\pm 3^{\circ} \mathrm{C}$. In leg 2 and 3, the spectrometer temperature was stable to $\pm 0.03^{\circ} \mathrm{C}$. The optical resolution is $0.5 \mathrm{~nm}$ FWHM (full width at half maximum), which was determined by measuring the second order of the $253.65 \mathrm{~nm}$ mercury emission line at $507.30 \mathrm{~nm}$ at beginning and end of the measurement campaign. This emission line was also used to determine the instrumental slit function and later to convolve high resolution literature cross sections to the optical resolution of our instrument. The measurement routine was controlled by a laptop PC and a CompactRio computer (model CompactRIO-9072, National Instruments Corp.). Both were operated fully automated by a custom Labview code and worked reliably during the whole measurement period. The target CCD saturation level for the spectra was set to $75 \%$. Spectra which reached the maximum CCD capacity of at least one wavelength channel of the detector because of light changes during acquisition were automatically rejected.

\subsection{Ship cruise}

The MAX-DOAS measurements over the tropical Pacific Ocean were conducted in the framework of two projects, (1) the VAMOS Ocean-Cloud-Atmosphere-Land Study - Regional Experiment (VOCALS-REx, see http://www.eol.ucar. edu/projects/vocals/) and (2) the Tropical Atmosphere Ocean (TAO, see http://www.pmel.noaa.gov/tao/). The cruise of the RV Ronald H. Brown during VOCALS-REx was split into two legs: leg 1 (20 October-3 November 2008) started upon entering the Ecuadorian waters coming from Panama. The vessel headed south to $20^{\circ} \mathrm{S}$ latitude and $85^{\circ} \mathrm{W}$ longitude where it stopped for a buoy replacement and then cruised eastwards to Arica, Chile. Leg 2 (9 November-3 December 2008) started in Arica going west to this buoy and back, however not straight, but with some deviations to North and South. The TAO leg (9 December 2008-11 January 2009) started from Arica and headed straight to $8^{\circ} \mathrm{S}$ and $95^{\circ} \mathrm{W}$ to service a line of ocean buoys going North. At $0^{\circ}$ latitude, the RV Ron Brown sailed to the $110^{\circ} \mathrm{W}$ buoy line continuing with buoys located from $8^{\circ} \mathrm{S}$ through $8^{\circ} \mathrm{N}$. Lastly, the buoys between $8^{\circ} \mathrm{N}$ and $2^{\circ} \mathrm{N}$ at the $95^{\circ} \mathrm{W}$ line were serviced before the vessel went straight to Panama City.

\subsection{The DOAS analysis}

The primary data product of the MAX-DOAS spectral analysis is the retrieval of the "differential Slant Column Density" (dSCD, difference between the actual SCD and the SCD of the Fraunhofer reference spectrum, FRS) for the trace gas of interest. The SCD is the integrated trace gas concentration along the light path. Thus the SCD depends on several parameters, namely the trace gas concentration profile, the measurement geometry, the sun's position and the optical properties of the atmosphere, which is mainly determined by clouds and aerosol load. To account for the complexity of the light path distribution, radiative transfer calculations were performed. This allows for interpretation of the measurements quantitatively by means of calculated "Air Mass Factors" (AMFs). The AMF expresses the light path ratio between the slant and the vertical path through the atmosphere (Solomon et al., 1987; Marquard et al., 2000).

We used the WinDOAS software package (Fayt and van Roozendael, 2001) from IASB (Belgium Institute for Space Aeronomy) to retrieve the CHOCHO dSCDs with the DOAS analysis of the measured spectra. Several trace gas cross sections as well as the logarithm of a FRS, a Ring spectrum (Grainger and Ring, 1962) and a polynomial of degree 3 were fitted to the logarithm of the acquired spectrum based on a non-linear least squares fitting algorithm. The Ring spectrum (calculated by the Software package DOASIS; Kraus, 2006) fulfills the purpose of correcting for Raman scattering and the polynomial for Rayleigh and aerosol extinction. Also included in the fitting routine was an intensity offset (linear polynomial) to account for instrumental stray light. The 
wavelength-pixel-mapping of the analyzed spectrum was allowed to shift against that of the FRS, the Ring spectrum and the cross sections (Stutz and Platt, 1996). In our retrieval the FRS and Ring spectra were continuously updated, and measurement spectra were analyzed relative to the closest FRS measured prior to the acquisition of the measurement spectrum. This procedure minimizes the influence of instrumental instabilities and largely eliminates absorptions of trace gases located in the stratosphere. The Ring spectrum was calculated from the appropriate FRS and was updated accordingly. Using WinDOAS, the wavelength-pixel-mapping was determined by fitting the FRS to a high resolution solar spectrum (Kurucz et al., 1984) convolved with the instrument's slit function. For the $\mathrm{CHOCHO}$ evaluation, a spectral range from 433 to $458 \mathrm{~nm}$ was chosen, encompassing two major $\mathrm{CHOCHO}$ absorption bands including the relatively strong band at around $455 \mathrm{~nm}$ (see Fig. 1).

The following high resolution absorption cross sections were included in the retrieval: CHOCHO (Volkamer et al., 2005b), $\mathrm{NO}_{2}$ at $294 \mathrm{~K}$ (Vandaele et al., 1997), ozone at $223 \mathrm{~K}$ (Bogumil et al., 2003) and $\mathrm{O}_{4}$ (Hermans et al., 1999). These cross sections were convolved with the instrumental slit function to match the spectral resolution of the instruments. In addition, we used a water vapor reference spectrum derived from our own atmospheric measurements on 11 November 2008, at 17:29 UT due to the poor quality of literature water vapor line parameters in the $\mathrm{CHOCHO}$ wavelength range (see Sinreich et al. (2007) and the references therein for details on the procedure). At this time, the ship was at $19.9^{\circ}$ South and $75.2^{\circ}$ West where CHOCHO was mostly below the detection limit. Since the water vapor reference spectrum was derived by the instrument itself, its specific optical properties inherently lead to a better spectral retrieval with less systematic structures. A comparison of two otherwise identical CHOCHO retrievals, one using our measured water vapor cross section and one using a water vapor cross section from literature (Rothman et al., 2009) led to indistinguishable results for the CHOCHO dSCDs within the spectral analysis uncertainty, but showed significantly larger residual structures when using the cross section from literature. There was no liquid water cross section included in the DOAS analysis since the measurements shown in this paper are all from sky spectra and only exceptionally hit the ocean (with its generally low albedo). For this reason, also a spectral artifact caused by chlorophyll in the water is highly unlikely for our MAX-DOAS measurements.

The $\mathrm{O}_{4}$ dSCDs were retrieved in the wavelength range between 465 and $486 \mathrm{~nm}$, from the strong absorption band at $477 \mathrm{~nm}$. Cross sections of $\mathrm{O}_{4}$ (Hermans et al., 1999), $\mathrm{NO}_{2}$ at $294 \mathrm{~K}$ (Vandaele et al., 1997), $\mathrm{H}_{2} \mathrm{O}$ (Rothman et al., 2009) and of $\mathrm{O}_{3}$ (Bogumil et al., 2003) were fitted. Furthermore, a Ring spectrum, a polynomial of degree 2 and a linear intensity offset were included in the fit.

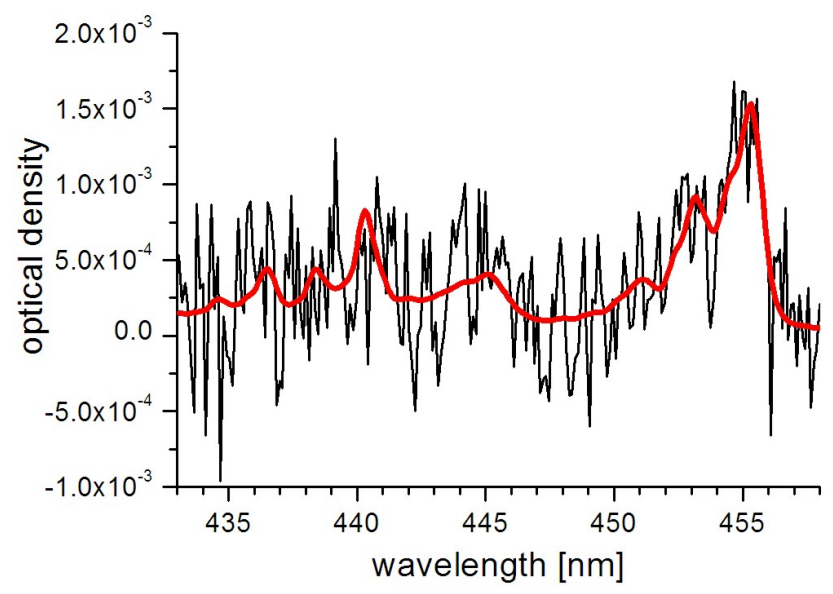

Fig. 1. Spectral retrieval for elevated $\mathrm{CHOCHO}$ (dSCD of $2.69 \times 10^{15} \mathrm{molec} / \mathrm{cm}^{2}$ and RMS of $0.37 \times 10^{-3}$ ). The example spectrum was recorded on 28 December 2008 at 03:29 p.m. UT at an elevation angle of $179.4^{\circ}$. The optical density of $\mathrm{CHOCHO}$ versus wavelength is shown in red, whereas the black line shows the sum of the scaled cross section and the residual.

\subsection{Quality assurance and data filtering}

The data set underwent several filters to eliminate a possible impact of ship exhaust to the data, to ensure a specific signalto-noise level, and to provide a subset of data with cloud-free conditions for retrieving volume mixing ratios (see Sect. 3.2).

- Ship exhaust: during the cruise and while on station to service buoys, the exhaust from the ship was blown into the line of sight of the MAX-DOAS device at times. In order to prevent the ship exhaust from contributing to the $\mathrm{CHOCHO}$ data set, the $\mathrm{NO}_{2}$ dSCDs (taken from the $\mathrm{CHOCHO}$ analysis) of $1.5^{\circ}, 90^{\circ}$ and $178.5^{\circ}$ were compared. In the open sea, in general, no significant tropospheric $\mathrm{NO}_{2}$ values are expected. If a significant tropospheric $\mathrm{NO}_{2}$ signal was detected in one of the shallow viewing directions but not in the vertical or the other shallow direction, the results were excluded for the whole measurement sequence of the respective pointing direction. However, close to the coast $\mathrm{NO}_{2}$ plumes from land could be measured. In those cases, a significant tropospheric $\mathrm{NO}_{2}$ signal was found in all three directions, and no filtering was applied.

- Signal-to-noise: only CHOCHO dSCDs above a conservative detection limit were considered (except for Fig. 2 where this filter is not applied). The dSCD detection limit was set to 2 times the root mean square of the fit residual divided by the strongest convolved (differential) cross section peak in the analysis wavelength window $\left(5 \times 10^{-19} \mathrm{~cm}^{2}\right.$; Volkamer et al., 2005b). 

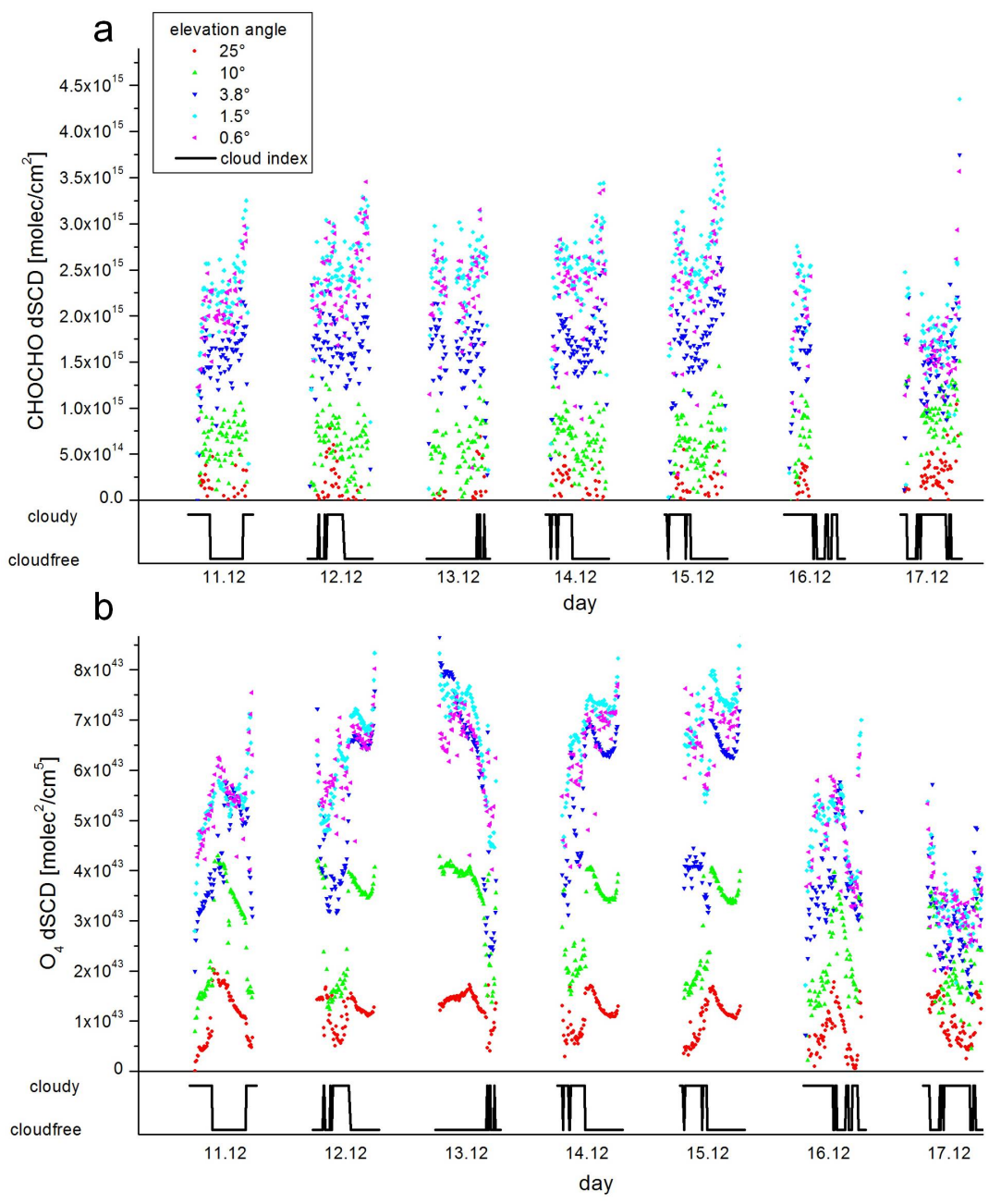

Fig. 2. (a) One week of the retrieved CHOCHO dSCDs from 11 through 17 December 2008. The elevation angles (color coded) are well separated except for the lowest elevation angles and on 17 December. A two level cloud index is added whereby the high value means cloudy conditions and the low value no clouds. (b) The same as (a) for $\mathrm{O}_{4}$ dSCDs.

- Cloud screening: the data set was divided into subsets of data according to whether clouds were present or not. In order to find a measure for cloudless conditions, a cloud index was developed based on the concept of a color index introduced by Wagner et al. (1998) and recently applied by Takashima et al. (2009). The ratio $\mathrm{R}$ (elevation angle) of the spectral intensities from the edges of the spectrometer's wavelength range $(420 \mathrm{~nm}$ and $520 \mathrm{~nm}$ ) was calculated for each spectrum to serve as a measure how "blue" the sky is. Higher values indicate a sky with fewer and thinner clouds and lower values represent more and thicker clouds. It turned out that the ratios are inversely proportional to elevation angle, reflecting the effect of scattering from sea spray aerosols that are more abundant close to the surface. However, they are not separated by elevation angle under cloudy conditions. Thus, the ratio of the color index at the $3.8^{\circ}$ elevation angle, $R(3.8)$, and the one at the $25^{\circ}$ elevation angle, $R(25)$, provide a sharp threshold between cloudy and sunny conditions. Both ratios cover a significant area of the sky. For elevation angles larger than $90^{\circ}$, the corresponding ratio was applied: $R(176.2) / R(155)$. The calculated ratios resulted in two significant maxima at about 1 (cloudy conditions) and 1.5 (cloud-free conditions), so that the value 1.3 was chosen as a suitable threshold between cloudy and cloud-free conditions. This classification was found to be consistent with campaign notes on cloudiness. The cloud index is plotted in Fig. 2a, b as a two-value index where the high value indicates cloudy conditions and the low value no clouds. 


\section{Results}

\subsection{Spectral retrieval of CHOCHO}

Spectral proof for the detection of $\mathrm{CHOCHO}$ is given in Fig. 1. The spectrum shows an example $\mathrm{CHOCHO}$ retrieval from a $30 \mathrm{~s}$ spectrum that was taken on 28 December 2008, at 03:29 p.m. UT at an elevation angle of $179.4^{\circ}\left(0.6^{\circ}\right.$ above the horizon). At this time the RV Ron Brown was cruising at about $1.5^{\circ} \mathrm{N}$ and $110.3^{\circ} \mathrm{W}$ at the most Western part of the whole cruise, about $2000 \mathrm{~km}$ from continental land. The fitted optical density of CHOCHO versus wavelength is shown in red, whereas the black line shows the sum of the scaled cross section and the residual. The root mean square (RMS) variation of the optical density of the residual in this evaluation is $3.7 \times 10^{-4}$ and the optical density of CHOCHO is about $1.5 \times 10^{-3}\left(\mathrm{dSCD}\right.$ of $\left.2.69 \times 10^{15} \mathrm{molec} / \mathrm{cm}^{2}\right)$ which is about 4 times the residual and about 9 times the fit error $\left(3.07 \times 10^{14} \mathrm{molec} / \mathrm{cm}^{2}\right)$.

Figure $2 \mathrm{a}$ and $\mathrm{b}$ show one week of $\mathrm{CHOCHO}$ and $\mathrm{O}_{4}$ dSCDs (in units of molec/ $\mathrm{cm}^{2}$ and in $\mathrm{molec}^{2} / \mathrm{cm}^{5}$, respectively) retrieved from multiple elevation angles at the beginning of the TAO leg from 11 through 17 December 2008. Since solar stray light MAX-DOAS requires sunlight no data is collected at night, which explains the gaps in the time series. For clarity, only the elevation angles pointing to one side of the ship (i.e. $0.6^{\circ}, 1.5^{\circ}, 3.8^{\circ}, 10^{\circ}$, and $25^{\circ}$ ) are shown and color coded, and we note that the dSCDs measured to the other side (i.e. $179.4^{\circ}$ to $155^{\circ}$ ) exhibited similar values. Due to the strong swell the $0.25^{\circ}$ (and $179.75^{\circ}$ ) elevation angle often pointed below the horizon at the sea surface, and this data is therefore omitted. Clearly, the CHOCHO dSCDs are separated by elevation angles and are higher in lower elevation angles, indicating that $\mathrm{CHOCHO}$ is enhanced near the instrument altitude, i.e. inside the Marine Boundary Layer (MBL). Notably, the dSCD values of $0.6^{\circ}$ and $1.5^{\circ}$ (as well as $179.4^{\circ}$ and $178.5^{\circ}$ ) lie mostly on top of each other, and $3.8^{\circ}$ (and $176.2^{\circ}$ ) on 17 December behaved the same as well. Such overlapping was observed during the whole measurement period. We have demonstrated elsewhere that this overlapping is typically caused by aerosol extinction (Volkamer et al., 2009b); the collapse of dSCDs of the lowest elevation angles onto an almost single value reflects the fact that the bulk of the scattering events are located inside the boundary layer. Also, the $\mathrm{O}_{4} \mathrm{dSCD}$ values of the lowest elevation angles in Fig. $2 b$ lie on top of each other, while values of higher elevation angles are clearly separated, which confirms the existence of elevated aerosol loads. A CHOCHO layer only aloft in the MBL or above as cause for the overlap at lower elevation angles seems to be very unlikely, since the overlapping dSCDs are seen in both $\mathrm{CHOCHO}$ and $\mathrm{O}_{4}$ dSCDs. For $\mathrm{O}_{4}$ the vertical profile shape is well known, with its bulk concentration in the lower troposphere. The sensitivity in the lower angles towards elevated layers is greatly reduced, and largely canceled out by our analysis using al- ways a zenith reference spectrum which is close in time to the measurement spectrum. If indeed $\mathrm{CHOCHO}$ aloft was enhanced to a point that it caused a turnover point, it would be visible in higher dSCDs measured in the higher elevation angles and decreasing dSCDs in the lower elevation angles. This is not observed. Furthermore, in both plots the two value cloud index introduced in Sect. 2.5 is shown. Figures 1 and 2a demonstrate for the first time that $\mathrm{CHOCHO}$ is located in the MBL over the tropical Pacific Ocean.

$\mathrm{CHOCHO}$ is highly water soluble and partitions readily to water droplets in clouds (Henry's law constant $H_{\text {eff }}=$ $4.2 \times 10^{5} \mathrm{M} / \mathrm{atm}$ at $298 \mathrm{~K}$; Ip et al., 2009). At a typical liquid water content of $1 \mathrm{~g} / \mathrm{m}^{3}$, about $90 \%$ of CHOCHO is dissolved in the cloud water and $10 \%$ is present in the gas phase (see Volkamer et al., 2009a). Indeed, the CHOCHO dSCDs of the $25^{\circ}$ elevation angle (red dots) often showed tendentially higher values when it was cloudy (higher cloud index value). This might indicate that even in clouds, the gas phase CHO$\mathrm{CHO}$ is still observable. In principle, this effect should also be seen for the other elevation angles. However, the relative contribution of the light paths inside clouds is smaller, and noise and other scattering effects are stronger or even dominant. Since $\mathrm{O}_{4}$ is not water soluble and the vertical profile is well known, even in the presence of clouds, $\mathrm{O}_{4}$ dSCDs provide a meaningful tracer of the photon path distribution. The effect of clouds is, typically, to decrease differences in the $\mathrm{O}_{4} \mathrm{dSCDs}$ of different elevation angles, most visible on 17 December. Under cloud free conditions, the $\mathrm{O}_{4}$ dSCDs of the different elevation angles are clearly separated and are more consistent.

Figure 3a shows the CHOCHO dSCDs of $1.5^{\circ}$ and $178.5^{\circ}$ elevation angle along the cruise track. Consistently higher values were retrieved during the TAO leg. The values typically vary between 1 and $3 \times 10^{15} \mathrm{molec} / \mathrm{cm}^{2}$ (individual values up to $6 \times 10^{15} \mathrm{molec} / \mathrm{cm}^{2}$ ), and higher values tend to be observed on the way from Arica to the first buoy and during the Western and Northern part of the cruise. However, the CHOCHO dSCD values reflect the overlap of photon light paths and $\mathrm{CHOCHO}$ distribution. The following section describes how the $\mathrm{O}_{4}$ dSCDs can be used to isolate light path effects to derive $\mathrm{CHOCHO}$ volume mixing ratios.

\subsection{Conversion of CHOCHO dSCDs into volume mixing ratios}

We used the radiative transfer model McArtim (Deutschmann, 2009) to convert CHOCHO dSCDs into volume mixing ratios and exploited the special feature of overlapping dSCDs at low elevation angles (up to $3.8^{\circ}$ ) to simplify this conversion, following principles introduced by Volkamer et al. (2009b). This approach is based on the observation that pointing below a certain angle yields dSCD values that are essentially indistinguishable within the analysis error. Consequently, the light path distributions of these lower angles must be very similar. This effect is attributed 

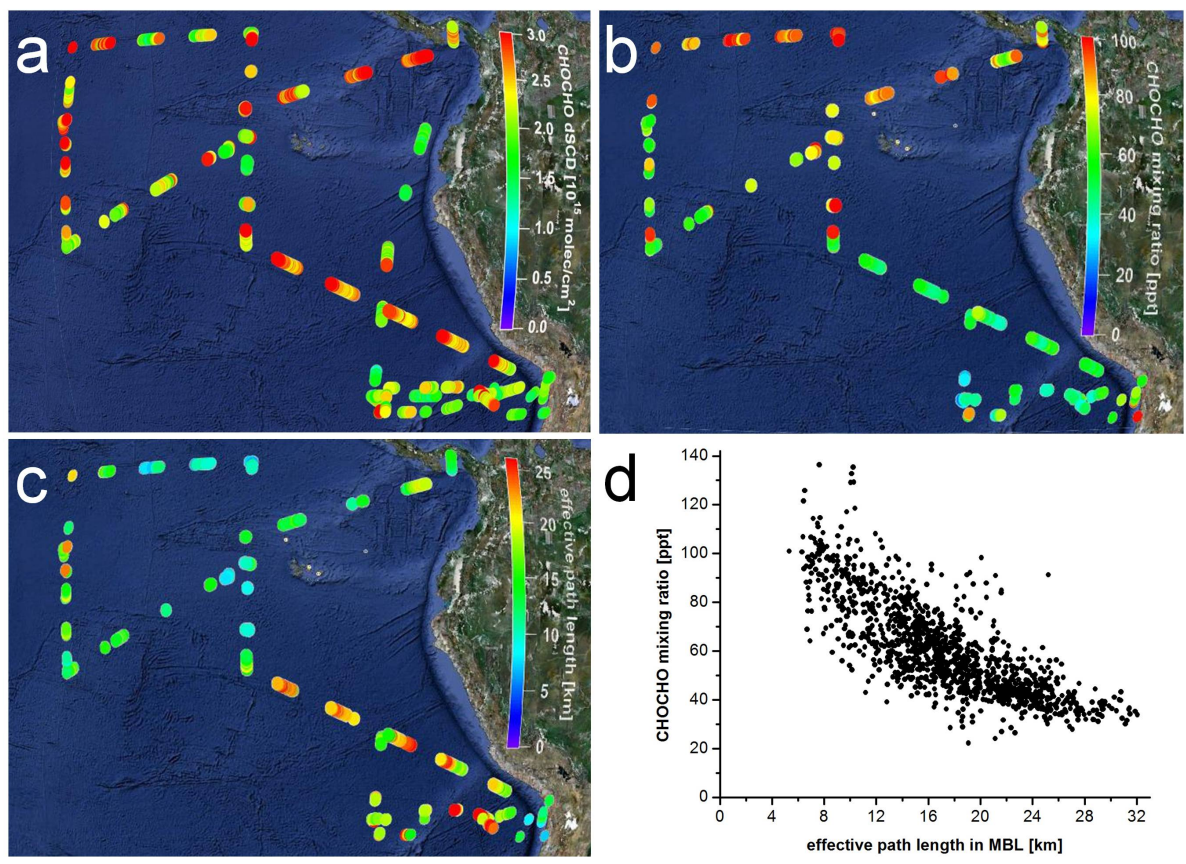

Fig. 3. Cruise plots (westerly of South America) of (a) $\mathrm{CHOCHO}$ dSCDs at $1.5^{\circ}$ and $178.5^{\circ}$ elevation angles, (b) $\mathrm{CHOCHO}$ volume mixing ratios (given in ppt) derived as described in Sect. 3.2, and (c) effective path length in the MBL (satellite underlay pictures: Google Earth). (d) Correlation plot of $\mathrm{CHOCHO}$ mixing ratio versus the effective path length, which shows an anti-correlation.

to aerosols: assuming a well mixed MBL the aerosol load is high enough so that the differences in path lengths, which usually arise within different elevation angles, are no longer observable. As shown in Fig. 2, the collapse of dSCDs is observed for CHOCHO (absorbing strongest at $455 \mathrm{~nm}$ ) as well as for $\mathrm{O}_{4}$ absorbing at $477 \mathrm{~nm}$.

The light path can be calculated from the $\mathrm{O}_{4}$ dSCDs and applied to the CHOCHO dSCDs. A correction factor calculated from radiative transfer modeling accounts for the difference in the absorption wavelengths and vertical profile shapes of the two trace gases. Volkamer et al. (2009b) demonstrated this for two cases in which the trace gas absorbs at the same wavelengths as $\mathrm{O}_{4}(360 \mathrm{~nm}$ and $477 \mathrm{~nm})$. Here we apply the same approach using $\mathrm{O}_{4}$ at $477 \mathrm{~nm}$ for estimating the effective light path of a CHOCHO layer absorbing at $455 \mathrm{~nm}$. The radiative transfer calculations give the correction factors, which, by means of the measured $\mathrm{O}_{4}$ dSCDs, provide the conversion of CHOCHO dSCDs into volume mixing ratios. The correction factors were calculated for different aerosol loads and different solar zenith angles (SZAs). For the modeling, an albedo of 0.05, a single scattering albedo of 0.97 and an aerosol asymmetry parameter of 0.75 were chosen. The CHOCHO layer is assumed to be located close to sea level with a constant mixing ratio up to a certain height (box profile), as well as the aerosol load being constant (relative to the air pressure) over this same height. These heights were set to a typical value of $1.5 \mathrm{~km}$ (Rahn and Garreaud, 2010; Kley et al., 1996). Sensitivity studies vary- ing MBL height showed little sensitivity for the low elevation angles used here, i.e. with $1 \mathrm{~km}$ layer height correction factors were $<24 \%$ different to those with $1.5 \mathrm{~km}$ height; comparisons with $2 \mathrm{~km}$ layer height yielded even smaller differences $(<5 \%)$. For deriving the correction factors, the aerosol extinction profile was chosen to reflect the typical behavior of the measured dSCDs (i.e. collapsing of the lowest elevation angles), and we derived mean correction factors for aerosol extinction values ranging from 0.2 to $0.6 \mathrm{~km}^{-1}$ aerosol extinction at ground level. For values below $0.2 \mathrm{~km}^{-1}$ the values of the small elevation angles typically separate, and above $0.6 \mathrm{~km}^{-1}$ the $3.8^{\circ}$ elevation angle clearly overlaps with the lower elevation angle values, which was not often observed in the measurements (see Volkamer et al., 2009b). In this interval the mean value was taken each and the standard deviation based on the variability within this interval was calculated for different SZAs. The correction factor was expressed as a function of the SZA (ranging between 0.61 and 0.87 ), and was applied to the dSCDs of CHOCHO for $1.5^{\circ}$ and $178.5^{\circ}$, using the light path calculated from the respective $\mathrm{O}_{4}$ dSCD values (assuming a $\mathrm{O}_{4}$ vertical column density (VCD) of $1.33 \times 10^{43} \mathrm{molec}^{2} / \mathrm{cm}^{5}$ and a $\mathrm{O}_{4}$ mean concentration of the lowest $1.5 \mathrm{~km}$ of $2.50 \times 10^{37} \mathrm{molec}^{2} / \mathrm{cm}^{6}$ ), assuming 1 part per trillion (ppt) is $2.5 \times 10^{7} \mathrm{molec} / \mathrm{cm}^{3}$. Above $80^{\circ} \mathrm{SZA}$, the correction factor increases significantly while the signal-to-noise decreases strongly, and no values above $80^{\circ}$ SZA were chosen for the conversion into mixing ratios. 
The radiative transfer modeling showed that a cloud cover makes a significant difference compared to the cloud-free scenario on which the calculations were based. Thus, the cloud filter described in Sect. 2.5 was used to remove all $1.5^{\circ}$ and $178.5^{\circ} \mathrm{dSCD}$ values that were measured under cloudy conditions. In order to ensure that the assumptions of the overlapping of dSCD values are met, only $1.5^{\circ}$ and $178.5^{\circ}$ values that did not deviate from the respective $0.6^{\circ}$ and $179.4^{\circ} \mathrm{dSCD}$ values by more than $20 \%$ were taken into account. This was valid for $86 \%$ of the values after the filters described in Sect. 2.5 were applied. The $14 \%$ that did not meet this criterion were not used for the mixing ratio conversion.

The overall error of the mixing ratio conversion is dominated by the assumptions of the approach, especially of the mixing layer height, and is at most $30 \%$, which also includes the DOAS fit error.

\section{Discussion}

Elevated CHOCHO mixing ratios of up to $140 \mathrm{ppt}$ were observed inside the MBL up to $3000 \mathrm{~km}$ from the continental coast. Figure $3 \mathrm{~b}$ shows the $\mathrm{CHOCHO}$ mixing ratio along the cruise track. The color coding has been capped at $100 \mathrm{ppt}$ to reflect most values and to emphasize their variability. During the TAO leg CHOCHO mixing ratios varied between $25 \mathrm{ppt}$ and $140 \mathrm{ppt}$ (see Fig. 3d) and were above the detection limit of few $10 \mathrm{ppt}$ almost everywhere in the probed area. The lowest $\mathrm{CHOCHO}$ mixing ratios were found near the buoy at $20^{\circ} \mathrm{S}$ and $85^{\circ} \mathrm{W}$, at the western tip of the most southern latitudes probed during the cruises. These mixing ratios correspond to a boundary layer vertical column of 0.9 to $5.3 \times 10^{14} \mathrm{molec} / \mathrm{cm}^{2}$, assuming a homogeneous box profile over a MBL height of $1 \mathrm{~km}$. The mean value amounts to $(2.1 \pm 0.7) \times 10^{14} \mathrm{molec} / \mathrm{cm}^{2}$. Also, the effective path length $L_{\text {eff }}$ in the MBL for our MAX-DOAS instrument was calculated from the observed $\mathrm{O}_{4} \mathrm{dSCDs}\left(L_{\text {eff }}=\mathrm{dSCD} /\right.$ mixing ratio) and are plotted in Fig. 3c. The lowest $L_{\text {eff }}$ values were observed during the Northwest part of the TAO leg, where the highest CHOCHO mixing ratios were found. Similarly, the highest values of $L_{\text {eff }}$ were found in the Southern part of the cruise, and correspond to the lowest $\mathrm{CHOCHO}$ mixing ratios on the cruise. The effective path length is related to the aerosol extinction; a shorter effective path length is primarily caused by higher aerosol extinction. Indeed, we observe an anti-correlation of the $\mathrm{CHOCHO}$ mixing ratio and the effective path length, as shown in Fig. 3d. CHOCHO uptake to aerosols is most efficient on aqueous aerosols (Liggio et al., 2005; Volkamer et al., 2009a), such as those of the tropical Pacific Ocean, and aerosol loss can affect the atmospheric life time of CHOCHO (Volkamer et al., 2007). The anti-correlation in Fig. 3d does not show a 1:1 correspondence, but rather reflects a complex coupling of CHOCHO and aerosols. Heald et al. (2006) stated that the GEOS-Chem global model underpredicts the organic aerosol concentrations observed in the MBL for different regions of the world, and invoked a missing organic aerosol source of $27 \mathrm{Tg} \mathrm{C} / \mathrm{yr}$ from the oceans that was correlated with photochemical activity. CHOCHO uptake to aerosols could potentially explain the observed organic aerosol concentrations in the MBL (Fu et al., 2008). However, Fig. 3d could equally be interpreted in terms of CHOCHO related aerosol sources (SOA formation), or be indicative of similar mechanisms forming aerosols and CHOCHO.

CHOCHO is very short lived, and any elevated CHOCHO indicates local sources. The atmospheric life time of CHO$\mathrm{CHO}$ is estimated to be about $2 \mathrm{~h}$ as a typical daytime value, and shorter at solar noon. It is determined primarily by the abundance of solar radiation around the Equator and, to a lesser extent, OH-initiated CHOCHO loss. The $24 \mathrm{~h}$ average $\mathrm{OH}$ concentration during VOCALS-REx was estimated to be $1.4 \times 10^{6} \mathrm{molec} / \mathrm{cm}^{3}$ (Yang et al., 2009), corresponding to a peak daytime $\mathrm{OH}$ of about $5 \times 10^{6} \mathrm{molec} / \mathrm{cm}^{3}$. This is in reasonable agreement with observations over the tropical Atlantic Ocean (on average several $10^{6} \mathrm{molec} / \mathrm{cm}^{3}$, though midday peaks reached almost $10^{7} \mathrm{molec} / \mathrm{cm}^{3}$; Whalley et al., 2010). We note that a primary $\mathrm{OH}$ radical source is from ozone photolysis, and ozone concentrations can be very low over the tropical Pacific Ocean (Kley et al., 1996). Thus, extrapolating measurements from the Atlantic to the Pacific Ocean may not be straightforward. For the following discussion, we assume $[\mathrm{OH}]=3 \times 10^{6} \mathrm{molec} / \mathrm{cm}^{3}$ as reasonable during daytime. Further, dry deposition of $\mathrm{CHOCHO}$ also can play an important role in a shallow MBL, since CHOCHO is highly water soluble $\left(H_{\text {eff }}=4.2 \times 10^{5} \mathrm{M} / \mathrm{atm}\right.$; Ip et al., 2009). With a typical deposition velocity of $3-4 \mathrm{~cm} / \mathrm{s}$, the CHOCHO loss to the ocean surface can add 20 to $30 \%$ to the daytime loss rate from photolysis and $\mathrm{OH}$ reaction; dry deposition is relatively more important at night. Also, CHOCHO uptake by aerosols to form SOA can compete with rapid gas-phase losses and will further lower the atmospheric lifetime of CHOCHO (Volkamer et al., 2007; Fu et al., 2008; Stavrakou et al., 2009; Ervens and Volkamer, 2010). The CHOCHO life time in the tropical Pacific Ocean is thus shorter than the global mean life time of CHOCHO (2.5 to 3 h; Myriokefalitakis et al., 2008; Fu et al., 2008; Stavrakou et al., 2009), and about comparable to that in urban photochemical hot-spots (Volkamer et al., 2005a, 2007). Given the short life time of $1-2 \mathrm{~h}$ during the day, we can rule out transport and oxidation of precursors emitted from terrestrial sources as a source of $\mathrm{CHOCHO}$. Typical precursors emitted over land are compounds like isoprene, toluene, and acetylene, which at an $\mathrm{OH}$ concentration of $3 \times 10^{6} \mathrm{molec} / \mathrm{cm}^{3}$ have atmospheric life times of about $1 \mathrm{~h}, 15 \mathrm{~h}$, and 5 days, respectively. Atmospheric models that represent land sources show enhanced CHOCHO only within few $100 \mathrm{~km}$ from the coast, but do not predict any $\mathrm{CHOCHO}$ over the remote tropical Pacific Ocean (Myriokefalitakis et al., 2008; Fu et al., 2008). This is consistent with the fact that typical transport 

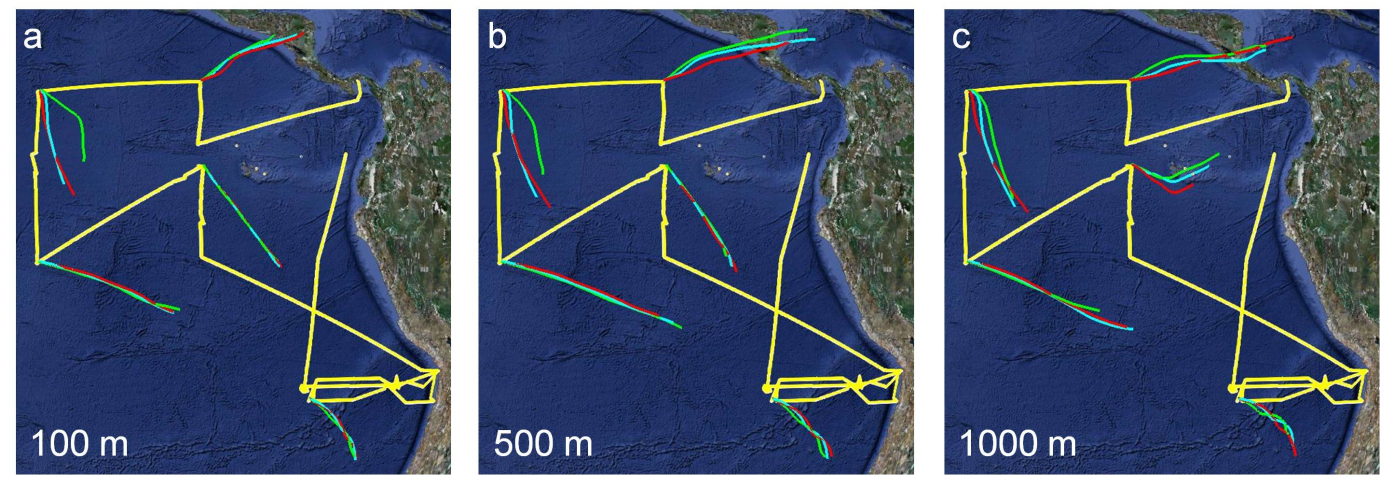

Fig. 4. $48 \mathrm{~h}$ HYSPLIT (HYbrid Single-Particle Lagrangian Integrated Trajectory) backward trajectory calculations for corner points of the cruise (yellow line) at the days the ship was there (Draxler and Rolph, 2010; Rolph, 2010). The trajectories are calculated for the morning (green), midday (turquoise) and evening (red) each for air mass heights at the starting points of (a) $100 \mathrm{~m}$, (b) $500 \mathrm{~m}$ and (c) $1000 \mathrm{~m}$ (satellite underlay pictures: Google Earth).

times over a $3000 \mathrm{~km}$ distance over the Pacific Ocean are much longer than the atmospheric life times of terrestrial precursors. An air mass coming directly from the continent would take about 1 week to reach the ship (at a wind speed of $5 \mathrm{~m} / \mathrm{s}$, about 10 knots). Figure 4 shows $48 \mathrm{~h}$ HYSPLIT (HYbrid Single-Particle Lagrangian Integrated Trajectory) backward trajectory calculations for corner points of the cruise (Draxler and Rolph, 2010; Rolph, 2010). The trajectories are calculated for days when the ship was passing through these points. They are shown for the morning (green), midday (turquoise) and evening (red), and for three different air mass heights $(100 \mathrm{~m}, 500 \mathrm{~m}$ and $1000 \mathrm{~m})$. The prevailing wind direction was southeast rather than coming directly from the continent, which is in good agreement with the ship's meteorology data. This prolongs the transport times from land sources considerably. Since a significant $\mathrm{CHOCHO}$ source due to continental outflow can be excluded, the observed elevated $\mathrm{CHOCHO}$ must originate from the ocean.

Kieber et al. (1990) showed that compounds like formaldehyde, acetaldehyde or glyoxylate are produced from the photochemical oxidation of Dissolved Organic Matter (DOM) in natural waters when exposed to sunlight. Millet et al. (2010) recently parameterized data from Kieber et al. (1990) and showed that DOM photochemistry in the ocean is the second largest global source for acetaldehyde ( $57 \mathrm{Tg} /$ year). Relying on the satellite retrievals of $\mathrm{CHOCHO}$, the spatial distribution of the acetaldehyde source indeed appears to somewhat resemble that of $\mathrm{CHOCHO}$ at tropical latitudes (Wittrock et al., 2006; Vrekoussis et al., 2009). However, we argue that this spatial correspondence is at least partly coincidental, and should not be taken as evidence that the CHOCHO source from the ocean follows the same oxidation mechanism as had been identified for acetaldehyde by Kieber et al. (1990). This is because $\mathrm{CHOCHO}$ is much more soluble than acetaldehyde (30000 times higher Henry's law constant). In order to explain $100 \mathrm{ppt}$ of boundary layer $\mathrm{CHOCHO}$ in equilibrium with ocean surface waters by means of a bulk ocean water photo oxidation mechanism, the ocean would need to be a $4 \times 10^{-5} \mathrm{M}$ concentrated solution of $\mathrm{CHOCHO}$. For comparison, the ocean concentration of acetaldehyde needed to explain atmospheric observations in Millet et al. (2010) (typically $20-200 \mathrm{ppt}$ ) is $1.3-20 \mathrm{nM}$. In fact, for CHOCHO the dissolved concentration would need to be even higher, since the atmospheric concentration of $\mathrm{CHOCHO}$ is not necessarily in steady state with the ocean due to rapid gas-phase losses and atmospheric dynamics. Typical concentrations of DOM in the tropical Eastern Pacific Ocean are 6-7 $\times 10^{-5} \mathrm{M}$ (Hansell et al., 2009), and a good fraction of this DOM has an essentially different molecular identity than CHOCHO. Typical CHOCHO concentrations in the air over open Caribbean Sea and Sargasso Sea were on the order of $80 \mathrm{ppt}$, and the corresponding seawater $\mathrm{CHOCHO}$ concentration was measured to be $0.5-5 \mathrm{nM}$ (Zhou and Mopper, 1990). CHOCHO concentrations measured $100 \mathrm{~km}$ east of the Bahamas were $0.3 \mathrm{nM}$ in the bulk ocean and about $6 \mathrm{nM}$ in the surface microlayer (Zhou and Mopper, 1997). Notably, CHOCHO is enriched by a factor of 4-20 in the surface microlayer compared to the bulk ocean reflecting a higher production rate from more abundant precursors (Zhou and Mopper, 1997), and/or radical sources (Reeser et al., 2009). However, Zhou and Mopper $(1990,1997)$ measured 4 orders of magnitude less $\mathrm{CHOCHO}$ in the surface microlayer than is compatible with equilibrium air-sea partitioning and atmospheric $\mathrm{CHO}$ $\mathrm{CHO}$ concentrations. Based on these measurements the net air-sea flux of $\mathrm{CHOCHO}$ is directed from the atmosphere into the ocean. This implies that the CHOCHO source over the Caribbean and Sargasso Sea was airborne. We find comparable $\mathrm{CHOCHO}$ concentrations over the tropical remote Pacific Ocean, where continental transport can be ruled out. If the above ocean measurements extrapolate to the tropical Pacific Ocean, it appears that a bulk water photochemical process can only explain a very minor portion $\left(\sim 10^{-4}-10^{-5}\right)$ of the CHOCHO source over the remote ocean. 
A simplified calculation using the SCIAMACHY CHOCHO VCDs, and the TM4 global model has quantified that to explain $\mathrm{CHOCHO}$ over the oceans requires a global source of $20 \mathrm{Tg} /$ year (Myriokefalitakis et al., 2008). This source could be related to oceanic emission of VOC precursors that form $\mathrm{CHOCHO}$ as the result of their oxidation in the atmosphere. The most important natural precursors are isoprene (CHOCHO yield is $8 \%$; Bey et al., 2001), toluene $(30 \%$ yield; Volkamer et al., 2005b), and acetylene (65\% yield; Hatekayama et al., 1986). Assuming an $\mathrm{OH}$ concentration of $3 \times 10^{6} \mathrm{molec} / \mathrm{cm}^{3}$ and an atmospheric life time of CHO$\mathrm{CHO}$ of $2 \mathrm{~h}$ (conservative upper limit), the VOC concentration needed to explain $100 \mathrm{ppt}$ of $\mathrm{CHOCHO}$ is either $600 \mathrm{ppt}$ of isoprene, $2.8 \mathrm{ppb}$ toluene, or $8.9 \mathrm{ppb}$ acetylene, or lower concentrations if multiple compounds were present. There are few observations of VOCs over the remote open ocean, and most of them focus on isoprene (Bonsang et al., 1992; Broadgate et al., 1997, 2004; Baker et al., 2000; Matsunaga et al., 2002; Meskhidze and Nenes, 2006; Yassaa et al., 2008). The currently measured isoprene concentrations do not exceed $40 \mathrm{ppt}$ and mostly are on the order of $10 \mathrm{ppt}$. All observations were made at higher latitudes than our probed area, but global estimates of isoprene concentration maps confirm these values for the probed area (Palmer and Shaw, 2005; Arnold et al., 2009; Gantt et al., 2009). Plass-Dülmer et al. (1995) derived a global upper limit for acetylene from ethane emissions over seawater of $0.16-0.54 \mathrm{Tg} / \mathrm{year}$, which on average corresponds to less than $20 \mathrm{ppt}$ acetylene. In lack of any measurements of toluene over the open sea, it seems unlikely to explain the observed $\mathrm{CHOCHO}$ production from secondary VOC chemistry over the open ocean. Thus neither continental outflow of VOC precursors from land sources, nor VOC emissions from the open ocean, nor a direct CHO$\mathrm{CHO}$ source from DOM photochemistry in the bulk ocean or surface microlayer are likely explanations for our observations. The high solubility of $\mathrm{CHOCHO}$ requires the source to be airborne, either in form of a process at the air-sea interface, or by a bubble bursting process. Further research is needed to determine the formation mechanism of $\mathrm{CHOCHO}$ over the remote tropical ocean.

\section{Conclusions}

The MAX-DOAS measurements onboard the research vessel Ronald H. Brown showed elevated CHOCHO differential Slant Column Densities (dSCDs) over the remote tropical Pacific Ocean, up to $3000 \mathrm{~km}$ from continental land sources. Ours are the first CHOCHO measurements in the remote marine boundary layer (MBL). Previous satellite measurements had also retrieved $\mathrm{CHOCHO}$ over the remote ocean, though different satellites give inconsistent values. The TM4 and GEOS-Chem models do not predict any CHOCHO over the open ocean (Myriokefalitakis et al., 2008; Fu et al., 2008), and currently cannot explain these observations.
By means of $\mathrm{O}_{4} \mathrm{dSCDs}$ and radiative transfer modelling the CHOCHO dSCDs of the $1.5^{\circ}$ and $178.5^{\circ}$ elevation angles were converted into mixing ratios, and the effective light paths in the MBL were estimated. Mixing ratios were typically $100 \pm 30 \mathrm{ppt}$, with higher values in the north-western part of the probed area (closer to the Equator); lower values were observed further south (typically around 40-50 ppt). An anti-correlation is observed between the CHOCHO mixing ratios, and the effective path length (an indicator for aerosol extinction). This is compatible with aerosol uptake of CHOCHO to form secondary organic aerosol (SOA), or could indicate similar mechanisms forming aerosols and CHOCHO.

The source of CHOCHO located up to $3000 \mathrm{~km}$ from continental land is unclear. Transport of $\mathrm{CHOCHO}$ or its precursors from terrestrial sources can be ruled out, due to the long travel time ( $>1$ week) of the air mass from the continental coast to reach the ship. Also, the production of $\mathrm{CHOCHO}$ by photo degradation of marine dissolved organic matter (DOM) in the ocean is unlikely to be an efficient source for atmospheric $\mathrm{CHOCHO}$ due to the high solubility of CHOCHO. However, an indirect link with DOM cannot be excluded. Lastly, the production of CHOCHO from VOC emissions would require VOC precursor amounts that are much higher than have been observed to date in the open ocean. The tropical Eastern Pacific Ocean is a particularly productive upwelling region and is a poorly probed atmospheric environment. More research is needed to understand the formation mechanism, and to quantify the impact of the reactive gas release from the open ocean on atmospheric chemistry, and possibly climate.

Acknowledgements. Financial support from NSF-SGER (ATM0827386), NSF-CAREER (AGS-0847793) and CU Boulder startup funds is gratefully acknowledged. We thank Rob Wood, Roberto Mechoso, Bob Weller, Chris Fairall, and the TAO program for accommodating the CU SMAX-DOAS on the cruise. The authors gratefully acknowledge the NOAA Air Resources Laboratory (ARL) for the provision of the HYSPLIT transport and dispersion model on the READY website (http://www.arl.noaa.gov/ready.php).

Edited by: H. Coe

\section{References}

Arnold, S. R., Spracklen, D. V., Williams, J., Yassaa, N., Sciare, J., Bonsang, B., Gros, V., Peeken, I., Lewis, A. C., Alvain, S., and Moulin, C.: Evaluation of the global oceanic isoprene source and its impacts on marine organic carbon aerosol, Atmos. Chem. Phys., 9, 1253-1262, doi:10.5194/acp-9-1253-2009, 2009.

Baker, A. R., Turner, S. M., Broadgate, W. J., Thompson, A., McFiggans, G. B., Vesperini, O., Nightingale, P. D., Liss, P. S., and Jickells, T. D.: Distribution and sea-air fluxes of biogenic trace gases in the eastern Atlantic Ocean, Global Biogeochem. Cy., 14, 871-886, 2000. 
Bey, I., Jacob, D. J., Yantosca, R. M., Logan, J. A., Field, B., Fiore, A. M., Li, Q., Liu, H., Mickley, L. J., and Schultz, M.: Global modeling of tropospheric chemistry with assimilated meteorology: Model description and evaluation, J. Geophys. Res., 106(D19), 23073-23095, 2001.

Bogumil, K., Orphal, J., Homann, T., Voigt, S., Spietz, P., Fleischmann, O. C., Vogel, A., Hartmann, M., Bovensmann, H., Frerik, J., and Burrows, J. P.: Measurements of Molecular Absorption Spectra with the SCIAMACHY Pre-Flight Model: Instrument Characterization and Reference Data for Atmospheric Remote-Sensing in the 230-2380 nm Region, J. Photochem. Photobiol. A., 157, 167-184, 2003.

Bonsang, B., Polle, C., and Lambert, G.: Evidence for marine production of isoprene, Geophys. Res. Lett., 19, 1129-1132, 1992.

Broadgate, W. J., Liss, P. S., and Penkett, S. A.: Seasonal emissions of isoprene and other reactive hydrocarbon gases from the ocean, Geophys. Res. Lett., 24, 2675-2678, 1997.

Broadgate, W., Malin, G., Kupper, F., Thompson, A., and Liss, P.: Isoprene and other non-methane hydrocarbons from seaweeds: a source of reactive hydrocarbons to the atmosphere, Mar. Chem., 88(1-2), 61-73, 2004.

Calvert, J. G., Atkinson, R., Becker, K. H., Kamens, R. H., Seinfeld, J. H., Wallington, T. J., and Yarwood, G. (Eds.): The mechanisms of atmospheric oxidation of aromatic hydrocarbons, Oxford Univ. Press, Oxford, 2002.

Calvert, J. G., Atkinson, R., Kerr, J. A., Madronich, S., Moortgat, G. K., Wallington, T. J., and Yarwood, G. (Eds.): The Mechanisms of Atmospheric Oxidation of the Alkenes, Oxford Univ. Press, New York, 2000.

Deutschmann, T.: Atmospheric Radiative Transfer Modelling with Monte Carlo Methods, Diploma thesis, Institute of Environmental Physics, University of Heidelberg, Germany, http://rtm.iup. uni-heidelberg.de/McArtim/, 2009.

Draxler, R. R. and Rolph, G. D.: HYSPLIT (HYbrid Single-Particle Lagrangian Integrated Trajectory) Model access via NOAA ARL READY Website (http://ready.arl.noaa.gov/HYSPLIT. php), NOAA Air Resources Laboratory, Silver Spring, MD, 2010.

Ervens, B. and Volkamer, R.: Glyoxal processing by aerosol multiphase chemistry: towards a kinetic modeling framework of secondary organic aerosol formation in aqueous particles, Atmos. Chem. Phys., 10, 8219-8244, doi:10.5194/acp-10-8219-2010, 2010.

Ervens, B., Feingold, G., Frost, G. J., and Kreidenweis, S. M.: A modeling study of aqueous production of dicarboxylic acids: 1. Chemical pathways and speciated organic mass production, J. Geophys. Res.-Atmos., 109, D15205, doi:10.1029/2003JD004387, 2004.

Fayt, C. and Roozendael, M.: WinDOAS 2.1. Software User Manual, 2001.

Frieß, U., Monks, P. S., Remedios, J. J., Rozanov, A., Sinreich, R., Wagner, T., and Platt, U.: MAX-DOAS $\mathrm{O}_{4}$ measurements: A new technique to derive information on atmospheric aerosols: 2. Modeling studies, J. Geophys. Res., 111, D14203, doi:10.1029/2005JD006618, 2006.

Fu, T.-M., Jacob, D. J., Wittrock, F., Burrows, J. P., Vrekoussis, M., and Henze, D. K.: Global budgets of atmospheric glyoxal and methylglyoxal, and implications for formation of secondary organic aerosols, J. Geophys. Res., 113, D15303,
doi:10.1029/2007JD009505, 2008.

Gantt, B., Meskhidze, N., and Kamykowski, D.: A new physically-based quantification of marine isoprene and primary organic aerosol emissions, Atmos. Chem. Phys., 9, 4915-4927, doi:10.5194/acp-9-4915-2009, 2009.

Grainger, J. F. and Ring, J.: Anomalous Fraunhofer line profiles, Nature, 193, p. 762, 1962.

Hansell, D. A., Carlson, C. A., Repeta, D. J., and Schlitzer, R.: Dissolved Organic Matter in the Ocean - A Controversy Stimulates New Insights, Oceanography, 22(4), 202-211, 2009.

Hatakeyama, S., Washida, N., and Akimoto, H.: Rate Constants and Mechanisms for the Reaction of Oh (Od) Radicals with Acetylene, Propyne, and 2-Butyne in Air at 297 +/- 2 K, J. Phys. Chem., 90, 173-178, 1986.

Heald, C. L., Jacob, D. J., Park, R. J., Alexander, B., Fairlie, T. D., Yantosca, R. M., and Chu, D. A.: Transpacific transport of Asian anthropogenic aerosols and its impact on surface air quality in the United States, J. Geophys. Res., 111, D14310, doi:10.1029/2005JD006847, 2006.

Heckel, A., Richter, A., Tarsu, T., Wittrock, F., Hak, C., Pundt, I., Junkermann, W., and Burrows, J. P.: MAX-DOAS measurements of formaldehyde in the Po-Valley, Atmos. Chem. Phys., 5, 909918, doi:10.5194/acp-5-909-2005, 2005.

Hönninger, G., von Friedeburg, C., and Platt, U.: Multi axis differential optical absorption spectroscopy (MAX-DOAS), Atmos. Chem. Phys., 4, 231-254, doi:10.5194/acp-4-231-2004, 2004.

Hönninger, G. and Platt, U.: The Role of BrO and its Vertical Distribution during Surface Ozone Depletion at Alert, Atmos. Environ., 36, 2481-2489, 2002.

Hermans, C., Vandaele, A. C., Carleer, M., Fally, S., Colin, R., Jenouvrier, A., Coquart, B, and Mérienne, M.-F.: Absorption Cross-Sections of Atmospheric Constituents: $\mathrm{NO}_{2}, \mathrm{O}_{2}$, and $\mathrm{H}_{2} \mathrm{O}$, Environ. Sci. Pollut. Res., 6(3), 151-158, 1999.

Ip, H. S. S., Huang, X. H. H., and Yu., J. Z.: Effective Henry's law constants of glyoxal, glyoxylic acid, and glycolic acid, Geophys. Res. Lett., 36, L01802, doi:10.1029/2008GL036212, 2009.

Kieber, R. J., Zhou, X. L., and Mopper, K.: Formation of carbonyl compounds from UV-induced photodegradation 5 of humic substances in natural waters: Fate of riverine carbon in the sea, Limnol. Oceanogr., 35, 1503-1515, 1990.

Kley, D., Crutzen, P. J., Smit, H. G. J., Vömel, H., Oltmans, S. J., Grassl, H., and Ramanathan, V.: Observations of Near-Zero Ozone Concentrations Over the Convective Pacific: Effects on Air Chemistry, Science, 274(5285), 230-233, doi:10.1126/science.274.5285.230, 1996.

Kraus, S.: DOASIS - A Framework design for DOAS, PhD Thesis, University of Heidelberg, Heidelberg, Germany, available at: http://hci.iwr.uni-heidelberg.de/publications/dip/2006/Kraus_ PhD2006.pdf, 2006.

Kreher, K., Fiedler, M., Gomer, T., Stutz, J., and Platt U.: The latitudinal distribution $\left(50^{\circ} \mathrm{N}-50^{\circ} \mathrm{S}\right)$ of $\mathrm{NO}_{2}$ and $\mathrm{O}_{3}$ in October/November 1990, Geophys. Res. Lett., 22(10), 1217-1220, doi:10.1029/95GL01113, 1995.

Kurosu, T., Chance, K., and Volkamer, R: Global Measurements of $\mathrm{OClO}, \mathrm{BrO}, \mathrm{HCHO}$, and $\mathrm{CHO}-\mathrm{CHO}$ from the Ozone Monitoring Instruments on EOS Aura. Eos Trans, AGU Fall Meet. Suppl., Abstract A54B-01 (ORAL), 5-9 December, San Francisco, CA, USA, 2005.

Kurucz, R. L., Furenlid, I., Brault, J., and Testerman, L.: Solar Flux 
Atlas from 296 to $1300 \mathrm{~nm}$. Technical Report, National Solar Observatory, 1984.

Lerot, C., Stavrakou, T., De Smedt, I., Müller, J.-F., and Van Roozendael, M.: Glyoxal vertical columns from GOME2 backscattered light measurements and comparisons with a global model, Atmos. Chem. Phys. Discuss., 10, 21147-21188, doi:10.5194/acpd-10-21147-2010, 2010.

Leser, H., Hönninger, G., and Platt, U.: MAX-DOAS measurements of $\mathrm{BrO}$ and $\mathrm{NO}_{2}$ in the marine boundary layer, Geophys. Res. Lett., 30(10), 1537, doi:10.1029/2002GL015811, 2003.

Liggio, J., Li, S.-M., and McLaren, R.: Reactive uptake of glyoxal by particulate matter, J. Geophys. Res., 110, D10304, doi:10.1029/2004JD005113, 2005.

Marquard, L. C., Wagner, T., and Platt, U.: Improved Air Mass Factor Concepts for Scattered Radiation Differential Optical Absorption Spectroscopy of Atmospheric Species, J. Geophys. Res., 105, 1315-1327, 2000.

Martin, M., Pöhler, D., Seitz, K., Sinreich, R., and Platt, U.: BrO measurements over the Eastern North-Atlantic, Atmos. Chem. Phys., 9, 9545-9554, doi:10.5194/acp-9-9545-2009, 2009.

Matsunaga, S., Mochida, M., Saito, T., and Kawamura, K.: In-situ measurement of isoprene in the marine air and surface seawater from the western North Pacific, Atmos. Environ., 36, 6051-6057, 2002.

Meskhidze, N. and Nenes, A.: Phytoplankton and Cloudiness in the Southern Ocean, Science, 314, 1419-1423, 2006.

Millet, D. B., Guenther, A., Siegel, D. A., Nelson, N. B., Singh, H. B., de Gouw, J. A., Warneke, C., Williams, J., Eerdekens, G., Sinha, V., Karl, T., Flocke, F., Apel, E., Riemer, D. D., Palmer, P. I., and Barkley, M.: Global atmospheric budget of acetaldehyde: 3-D model analysis and constraints from in-situ and satellite observations, Atmos. Chem. Phys., 10, 3405-3425, doi:10.5194/acp-10-3405-2010, 2010.

Myriokefalitakis, S., Vrekoussis, M., Tsigaridis, K., Wittrock, F., Richter, A., Brühl, C., Volkamer, R., Burrows, J. P., and Kanakidou, M.: The influence of natural and anthropogenic secondary sources on the glyoxal global distribution, Atmos. Chem. Phys., 8, 4965-4981, doi:10.5194/acp-8-4965-2008, 2008.

Palmer, P. I. and Shaw, S. L.: Quantifying global marine isoprene fluxes using MODIS chlorophyll observations, J. Geophys. Res., 32, L09805, doi:10.1029/2005GL022592, 2005.

Plass-Dülmer, C., Koppmann, R., Ratte, M., and Rudolph, J.: Light nonmethane hydrocarbons in seawater, Global Biogeochem. Cy., 9, 79-100, 1995.

Platt, U.: Differential optical absorption spectroscopy (DOAS), Air monitoring by spectroscopic techniques, M.W. Sigrist, Ed., Chemical Analysis Series, 127, John Wiley \& Sons, Inc., 1994.

Platt, U.: Modern Methods of the Measurement of Atmospheric Trace Gases, Phys. Chem. Chem. Phy., 1, 5409-5415, 1999.

Rahn, D. A. and Garreaud, R.: Marine boundary layer over the subtropical southeast Pacific during VOCALS-REx - Part 1: Mean structure and diurnal cycle, Atmos. Chem. Phys., 10, 4491-4506, doi:10.5194/acp-10-4491-2010, 2010.

Reeser, D. I., Jammoul, A., Clifford, D., Brigante, M., D’ Anna, B., George, C., and Donaldson, D. J.: Photoenhanced Reaction of Ozone with Chlorophyll at the Seawater Surface, J. Phys. Chem. C, 113, 2071-2077, doi:10.1021/jp805167d, 2009.

Rolph, G. D.: Real-time Environmental Applications and Display sYstem (READY) Website (http://ready.arl.noaa.gov), NOAA
Air Resources Laboratory, Silver Spring, MD, 2010.

Rothman, L. S., Gordon, I. E., Barbe, A., Benner, D. C., Bernath, P. F., Birk, M., Boudon, V., Brown, L. R., Campargue, A., Champion, J.-P., Chance, K., Coudert, L. H., Dana, V., Devi, V. M., Fally, S., Flaud, J.-M., Gamache, R. R., Goldman, A., Jacquemart, D., Kleiner, I., Lacome, N., Lafferty, W. J., Mandin, J.Y., Massie, S. T., Mikhailenko, S. N., Miller, C. E., MoazzenAhmadi, N., Naumenko, O. V., Nikitin, A. V., Orphal, J., Perevalov, V. I., Perrin, A., Predoi-Cross, A., Rinsland, C. P., Rotger, M., Šimeková, M., Smith, M. A. H., Sung, K., Tashkun, S. A., Tennyson, J., Toth, R. A., Vandaele, A. C., and Auwera, J. V.: The HITRAN 2008 molecular spectroscopic database, J. Quant. Spectrosc. Ra., 110, 533-572, 2009.

Sinreich, R., Frieß, U., Wagner, T., and Platt, U.: Multi axis differential optical absorption spectroscopy (MAX-DOAS) of gas and aerosol distributions, Faraday Discuss., 130(08), doi:10.1039/b419274, 2005.

Sinreich, R., Volkamer, R., Filsinger, F., Frieß, U., Kern, C., Platt, U., Sebastián, O., and Wagner, T.: MAX-DOAS detection of glyoxal during ICARTT 2004, Atmos. Chem. Phys., 7, 1293-1303, doi:10.5194/acp-7-1293-2007, 2007.

Solomon, S., Schmeltekopf, A. L., and Sanders, R. W.: On the interpretation of zenith sky absorption measurements, J. Geophys. Res., 92, 8311-8319, 1987.

Stavrakou, T., Müller, J.-F., De Smedt, I., Van Roozendael, M., Kanakidou, M., Vrekoussis, M., Wittrock, F., Richter, A., and Burrows, J. P.: The continental source of glyoxal estimated by the synergistic use of spaceborne measurements and inverse modelling, Atmos. Chem. Phys., 9, 8431-8446, doi:10.5194/acp-9-8431-2009, 2009.

Stutz, J. and Platt, U.: Numerical Analyses and Estimation of the Statistical Error of Differential Optical Absorption Spectroscopy Measurements with Least Square Methods, Appl. Opt., 35, 6041-6053, 1996.

Takashima, H., Irie, H., Kanaya, Y., Shimizu, A., Aoki, K., and Akimoto, H.: Atmospheric aerosol variations at Okinawa Island in Japan observed by MAX-DOAS using a new cloud screening method, J. Geophys. Res., 114, D18213, doi:10.1029/2009JD011939, 2009.

van Roozendael, M., Fayt, C., Post, P., Hermans, C., and Lambert, J.-C.: Retrieval of $\mathrm{BrO}$ and $\mathrm{NO}_{2}$ from UV-Visible Observations, in: Sounding the troposphere from space: a new era for atmospheric chemistry, Springer-Verlag, ISBN 3-540-40873-8, edited by: Borell, P., Borell, P. M., Burrows, J. P., and Platt, U., Troposat: Eurotrac-2 Subproject Final Report, 2003.

Vandaele, A. C., Hermans, C., Simon, P. C., Carleer, M., Colin, R., Fally, S., Mérienne, M.-F., Jenouvrier, A., and Coquart, B.: Measurements of the $\mathrm{NO}_{2}$ Absorption Cross-section from 42000 $\mathrm{cm}^{-1}$ to $10000 \mathrm{~cm}^{-1}(238-1000 \mathrm{~nm})$ at $220 \mathrm{~K}$ and $294 \mathrm{~K}, \mathrm{~J}$. Quant. Spectrosc. Ra., 59, 171-184, 1997.

Volkamer, R., Platt, U., and Wirtz, K.: Primary and Secondary Glyoxal Formation from Aromatics: Experimental Evidence for the Bicycloalkyl-Radical Pathway from Benzene, Toluene, and pXylene, J. Phys. Chem. A, 105, 7865-7874, 2001.

Volkamer, R., Molina, L. T., Molina, M. J., Shirley, T., and Brune, W. H.: DOAS measurement of glyoxal as an indicator for fast VOC chemistry in urban air, J. Geophys. Res., 32, L08806, doi:10.1029/2005GL022616, 2005a.

Volkamer, R., Spietz, P., Burrows, J. P., and Platt, U., High- 
resolution absorption cross-section of Glyoxal in the UV/vis and IR spectral ranges, J. Photochem. Photobiol. A, 172, 35-46, doi:10.1016/j.jphotochem.2004.11.011, 2005b.

Volkamer, R., Jimenez, J. L., San Martini, F., Dzepina, K., Zhang, Q., Salcedo, D., Molina, L. T., Worsnop, D. R., and Molina, M. J.: Secondary Organic Aerosol Formation from Anthropogenic Air Pollution: Rapid and Higher than Expected, Geophys. Res. Lett., 33(17) L17811, doi:10.1029/2006GL026899, 2006.

Volkamer, R., San Martini, F., Salcedo, D., Molina, L. T., Jimenez, J. L., and Molina, M. J.: A missing sink for gas-phase glyoxal in Mexico City: Formation of secondary organic aerosol, Geophys. Res. Lett., 34, L19807, doi:10.1029/2007GL030752, 2007.

Volkamer, R., Ziemann, P. J., and Molina, M. J.: Secondary Organic Aerosol Formation from Acetylene $\left(\mathrm{C}_{2} \mathrm{H}_{2}\right)$ : seed effect on SOA yields due to organic photochemistry in the aerosol aqueous phase, Atmos. Chem. Phys., 9, 1907-1928, doi:10.5194/acp9-1907-2009, 2009a.

Volkamer, R., Coburn, S., Dix, B., and Sinreich, R.: MAX-DOAS observations from ground, ship, and research aircraft: maximizing signal-to-noise to measure 'weak' absorbers, Proc. SPIE, Vol. 7462, 746203, doi:10.1117/12.826792, 2009b.

Volkamer, R., Coburn, S., Dix, B., and Sinreich, R., The Eastern Pacific Ocean is a source for short lived trace gases: Glyoxal and Iodine Oxide, Clivar Exchanges April 2010, Vol. 15, No. 2, 2010.

Vrekoussis, M., Wittrock, F., Richter, A., and Burrows, J. P.: Temporal and spatial variability of glyoxal as observed from space, Atmos. Chem. Phys., 9, 4485-4504, doi:10.5194/acp-9-44852009, 2009.

Vrekoussis, M., Wittrock, F., Richter, A., and Burrows, J. P.: GOME-2 observations of oxygenated VOCs: what can we learn from the ratio glyoxal to formaldehyde on a global scale?, Atmos. Chem. Phys., 10, 10145-10160, doi:10.5194/acp-1010145-2010, 2010.

Wagner, T., Erle, F., Marquard, L., Otten, C., Pfeilsticker, K., Senne, T., Stutz, J., and Platt, U.: Cloudy sky optical paths as derived from differential optical absorption spectroscopy observations, J. Geophys. Res., 103(D19), 25307-25321, 1998.

Wagner, T., Dix, B., v. Friedeburg, C., Frieß, U., Sanghavi, S., Sinreich, R., and Platt, U.: MAX-DOAS $\mathrm{O}_{4}$ measurements: A new technique to derive information on atmospheric aerosols - Principles and information content, J. Geophys. Res., 109, D22205, doi:10.1029/2004JD004904, 2004.
Wagner, T., Ibrahim, O., Sinreich, R., Frieß, U., von Glasow, R., and Platt, U.: Enhanced tropospheric BrO over Antarctic sea ice in mid winter observed by MAX-DOAS on board the research vessel Polarstern, Atmos. Chem. Phys., 7, 3129-3142, doi:10.5194/acp-7-3129-2007, 2007.

Whalley, L. K., Furneaux, K. L., Goddard, A., Lee, J. D., Mahajan, A., Oetjen, H., Read, K. A., Kaaden, N., Carpenter, L. J., Lewis, A. C., Plane, J. M. C., Saltzman, E. S., Wiedensohler, A., and Heard, D. E.: The chemistry of $\mathrm{OH}$ and $\mathrm{HO}_{2}$ radicals in the boundary layer over the tropical Atlantic Ocean, Atmos. Chem. Phys., 10, 1555-1576, doi:10.5194/acp-10-1555-2010, 2010.

Wittrock, F., Oetjen, H., Richter, A., Fietkau, S., Medeke, T., Rozanov, A., and Burrows, J. P.: MAX-DOAS measurements of atmospheric trace gases in Ny-lesund - Radiative transfer studies and their application, Atmos. Chem. Phys., 4, 955-966, doi:10.5194/acp-4-955-2004, 2004.

Wittrock, F., Richter, A., Burrows, J. P., Kanakidou, M., Volkamer, R., Beirle, S., Platt, U., and Wagner, T.: Simultaneous Global Observations of Glyoxal and Formaldehyde from Space, Geophys. Res. Lett., 33, L16804, doi:10.1029/2006GL026310, 2006.

Yang, M., Blomquist, B. W., and Huebert, B. J.: Constraining the concentration of the hydroxyl radical in a stratocumulus-topped marine boundary layer from sea-to-air eddy covariance flux measurements of dimethylsulfide, Atmos. Chem. Phys., 9, 92259236, doi:10.5194/acp-9-9225-2009, 2009.

Yassaa, N., Peeken, I., Zöllner, E., Bluhm, K., Arnold, S., Spracklen, D., and Williams, J.: Evidence for marine production of monoterpenes, Environ. Chem., 5, 391-401, doi:10.1071/EN08047, 2008.

Zhou, X. and Mopper, K.: Apparent partition coefficients of 15 carbonyl compounds between air and seawater and between air and freshwater; implications for air-sea exchange, Environ. Sci. Technol., 24, 1864-1869, 1990.

Zhou, X. and Mopper, K.: Photochemical production of lowmolecular-weight carbonyl compounds in seawater and surface microlayer and their air-sea exchange, Mar. Chem., 56, 201-213, 1997. 